\title{
Before the spatial analysis of Beg-er-Vil: A journey through the multiple archaeological dimensions of a Mesolithic dwelling in Atlantic France
}

\author{
Grégor Marchand $^{\mathrm{a}, *}$, Catherine Dupont ${ }^{\mathrm{a}}$, Marine Laforge ${ }^{\mathrm{b}}$, Jean-Christophe Le Bannier ${ }^{\mathrm{a}}$, \\ Camille Netter $^{\mathrm{a}}$, Diana Nukushina ${ }^{\mathrm{c}}$, Marylise Onfray ${ }^{\mathrm{d}}$, Guirec Querré $^{\mathrm{a}}$, Laurent Quesnel ${ }^{\mathrm{a}}$, \\ Pierre Stéphan ${ }^{\mathrm{e}}$ \\ a UMR 6566 du CNRS, CREAAH, Laboratoire Archéosciences, Bâtiment 24-25, Université de Rennes 1, CS74205, 35042 Rennes Cedex, France \\ b Eveha et UMR 6566 du CNRS, CREAAH, Laboratoire Archéosciences, Bâtiment 24-25, Université de Rennes 1, CS74205, 35042 Rennes Cedex, France \\ c Universidade de Lisboa, Faculdade de Letras, UNIARQ, Centro de Arqueologia da Universidade de Lisboa, Alameda da Universidade, 1600-214 Lisboa, Portugal \\ ' Université Paris 1, UMR 8215, Unité sol UFR DMOS AgroParisTech, Maison de l'Archéologie \& Ethnologie, 21 allée de l'Université, 92023 Nanterre Cedex, France \\ e LETG UMR6554, Institut Universitaire Européen de la Mer, Place Nicolas Copernic, 29280 Plouzané, France
}

\section{A R T I C L E I N F O}

\section{Keywords:}

Mesolithic

Micromorphology

Sea-level index points

Shell midden

\begin{abstract}
A B S T R A C T
The Beg-er-Vil coastal site (Quiberon, Morbihan, France), initially excavated in the 1980s, and more extensively since 2012, is exposed to strong marine and anthropic erosion. At the present time, the main challenge is to define the status of the site by describing its formation dynamics. This necessitates investigating the taphonomic and erosive mechanisms using a combined method adapted to the shell midden levels, before undertaking spatial analysis. The archaeological level is protected by a thick dune and is subdivided into several stratigraphic units (SU), which record several changes in the function of the site. It is made up of accumulations of shell pockets covered in sandy sediments. The micromorphological analysis shows that this waste area seems to develop into an area of activities and movement. These surfaces also record alternating dry and wet seasonal conditions, but with no phase of abandonment. Systematic $\mathrm{pH}$ measurements show variations of 7.7 to 9.0 depending on the layers, corresponding to a slightly alkaline to alkaline acid-basic status. The mapping of measurements can be correlated to structures and archaeological remains of organic origin. The excavation shows that the division of the dwelling area was guided by topographic factors, with a circular dwelling $3.50 \mathrm{~m}$ in diameter installed on a flat zone and a shell waste zone on a slope towards the sea. Numerous fire-related activities were also carried out in this zone (pits, hearths). Spatial analysis by GIS shows a high concentration of recorded objects (lithics, bones, shells) to the west of the excavated area, in the shell level. Marine erosion is the main erosive factor limiting our knowledge of the site. The distance to the coastline was estimated after reconstruction of the relative sea level during the Holocene using the "Sea-Level Index Points" (SLIPs) methodology. Three SLIPs indicate a relative sealevel position between $-15.5 \mathrm{~m}$ and $-11 \mathrm{~m}$ and a foreshore area at a depth between -7.15 and $-14.02 \mathrm{~m}$ around $6200 \mathrm{BCE}$. This paleogeographic reconstruction approach indicates that the site of Beg-er-Vil was located a few hundred to a few kilometres from the coastline.
\end{abstract}

\section{Scientific position}

It was imperative to resume the excavation of the Beg-er-Vil shell midden (Quiberon townland, Morbihan department, France) in 2012, as marine erosion is gradually eating away the cliff on which the archaeological site is located, and anthropic pressure in this coastal resort is gradually altering it (trampling, vehicle circulation, coastal development).
This excavation is part of broader reflections on hunter-gatherer societies in coastal areas during the Holocene, and in particular on the social organization of these societies (Yesner, 1980; Testart, 1982; Sassaman, 2004; Kelly, 2007). Current research focuses on the functioning of the related mobility systems, partly based on marine circulation on the islands (Dupont et al., 2009; Marchand, 2013, 2014). This involves a detailed analysis of the littoral dwellings, which are considered to be the nodes in a network of exploitation of maritime and

\footnotetext{
* Corresponding author.

E-mail addresses: gregor.marchand@univ-rennes1.fr (G. Marchand), catherine.dupont@univ-rennes1.fr (C. Dupont), marine.laforge@eveha.fr (M. Laforge),

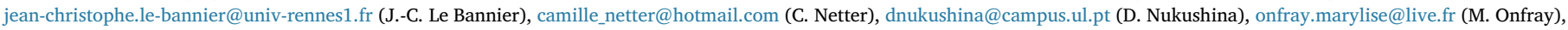
guirec.querre@univ-rennes1.fr (G. Querré), laurent.quesnel@univ-rennes1.fr (L. Quesnel), pierre.stephan@univ-brest.fr (P. Stéphan).
} 


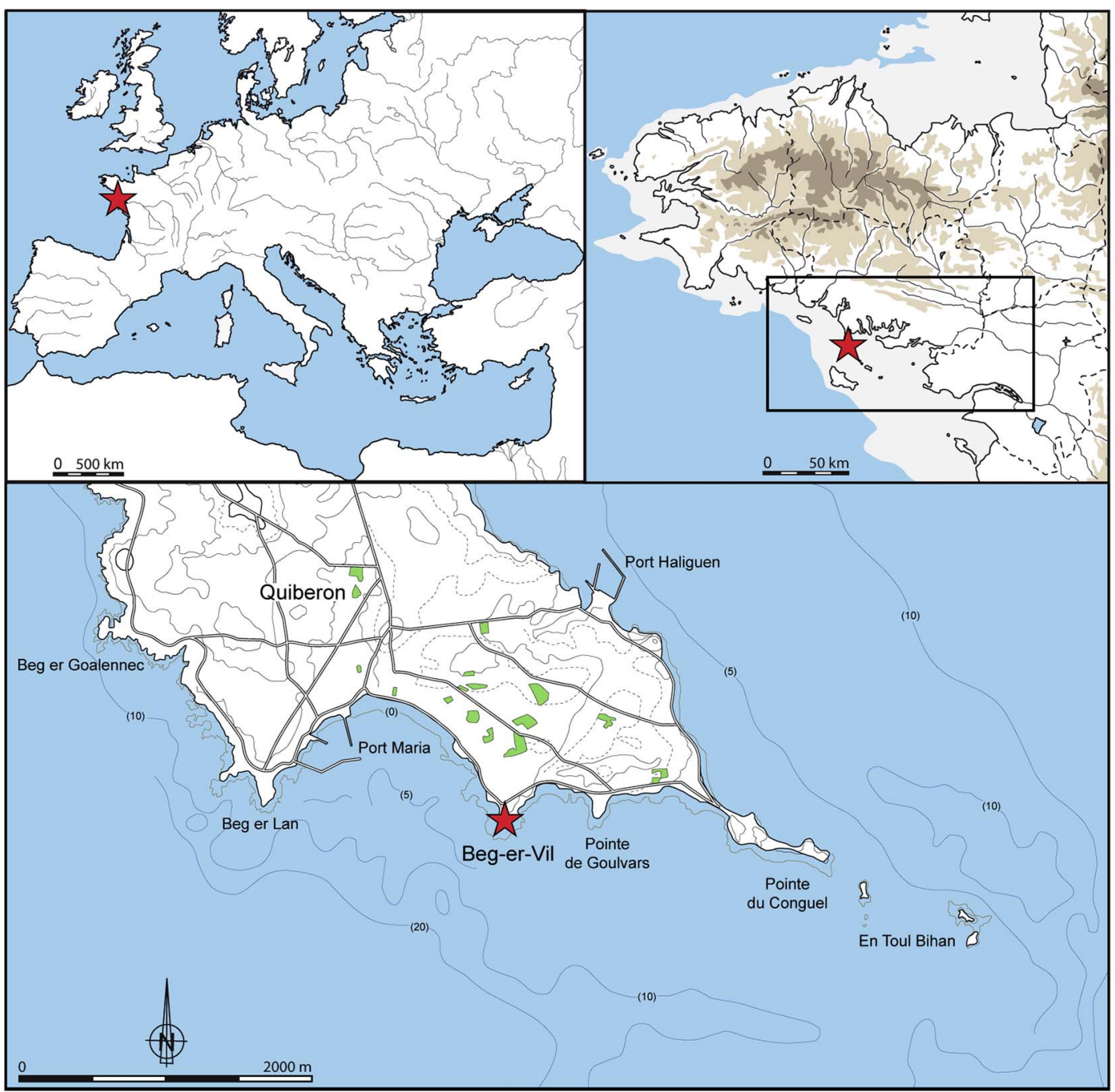

Fig. 1. Location of the site at the southern extremity of the peninsula (CAD: L. Quesnel).

terrestrial resources, as regards the chronology and the functioning of the occupations.

The site of Beg-er-Vil was remarkably conserved beneath a dune, but nonetheless required lengthy reconstitution work. The approach applied here is, as of yet, unique for the French Mesolithic on account of the diversity of the scientific methods involved. This article focuses on understanding the formation of the shell midden by the human occupants, its internal evolution after the abandonment of the site and the erosive forces that limit our understanding of the site. Each of these parameters represents filters that must be understood in order to provide a quality paleoethnolographic analysis.

\section{Excavations from 1985 to 2016}

The Quiberon peninsula is $11 \mathrm{~km}$ long from north to south by the Atlantic Ocean and Beg-er-Vil is located in the southernmost part, in a maritime zone dotted with several islands (Groix, Belle-île, Houat, Hoedic; Fig. 1). It is positioned in a small creek on the western side of a leucogranite head, only $5 \mathrm{~m}$ above the highest tides and very exposed to the elements. The archaeological site is clearly visible in the cliff as a single black-coloured level, filled with shells, crustacean remains, knapped flint, burnt rocky blocks and bones (fish, birds, mammals). This level is between a Pleistocene beach and a 0.30 to $1.8 \mathrm{~m}$ thick dune that extends throughout this part of Quiberon. The site was discovered in 1970, and was explored over $22 \mathrm{~m}^{2}$ by O. Kayser between 1985 and 1988 (Kayser and Bernier, 1988). New excavations have been in progress since 2012, not only on the shell midden, but also on its surroundings (Marchand et al., 2016; Marchand, Dupont, 2017). In October 2016, $240 \mathrm{~m}^{2}$ were mechanically stripped and partially excavated. At this point $120 \mathrm{~m}^{2}$ were excavated, including $57 \mathrm{~m}^{2}$ in the shell level. The total estimated surface of the shell midden is about $130 \mathrm{~m}^{2}$ (Fig. 2), but it is clearly impossible to estimate the surface removed by marine erosion. The Mesolithic occupation extends all around the shell level in a single silty-sandy level with a thickness of about $0.30 \mathrm{~m}$, and was sealed by the dunes and a recent car park.

\section{Formation dynamics of the shell level}

\subsection{General stratigraphy}

The stratigraphy established in the shell zone in the 1980s is strictly comparable to that of the 2010s, but initial work at the site focused on the thickest zone of the midden. The seemingly homogeneous archaeological level viewed from the cliff comprises several phases, described here from the base to the top.

- SU 7 is a 5-cm thick, orange-coloured, clayey-silty layer containing quartz pebbles stripped from the former beach and with no archaeological objects.

- SU 6 is a black-coloured, 5-cm thick layer of sands, with numerous crushed marine mollusc shells, and containing Mesolithic tools.

- SU 5.3 to 5.5 are black-coloured, sandy-silty layers with a total 


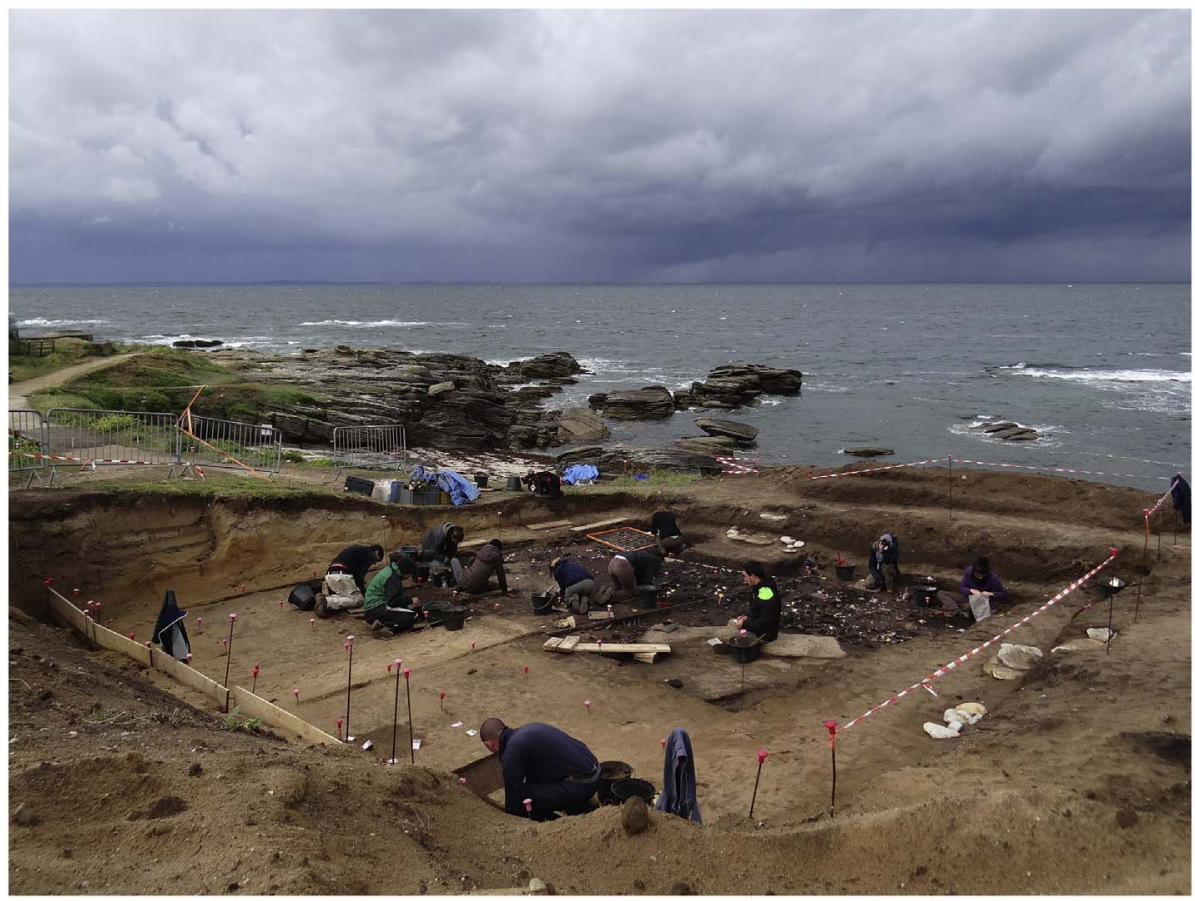

Fig. 2. General view of the excavation of the site in 2014 with the shell layer in black and the sandy level all around (Picture: G. Marchand).

thickness of 10 to $15 \mathrm{~cm}$, with numerous rubified granitic blocks, comprising the main dwelling structures (pits and hearths).

- SU 5.1 and 5.2 are black, sandy-silty layers ranging in thickness from 10 to $15 \mathrm{~cm}$, with numerous crushed marine mollusc shells, Mesolithic flints and animal bones.

- SU 4 is a brown sandy layer with silty aggregates, without shells, but with archaeological objects.

What are the formation processes of these shell deposits? What do they reflect in terms of the functioning of the dwelling and spatial occupation dynamics?

\subsection{Successive accumulations of shells (SU 5.1 to 5.5)}

Since the beginning of the renewed excavations in 2012, the thickness of the shell level we observed is less important than that observed by O. Kayser in the 1980s, during work carried out on the edge of the cliff (Fig. 3). This observation concurs with the discovery of the limit of the shell level during the new excavations. One of our longterm aims is to assess the consequences of this progressive reduction of the shell midden on the conservation of faunal remains. We also wish to find out whether the malacofaunal composition is similar over the whole shell level surface or if it corresponds to specific accumulation rhythms. The answers to these questions are still partial. In order to reply fully, we will have to sort and count hundreds of kilos of faunal remains, which have already been wet-sieved with meshes of 2 and $4 \mathrm{~mm}$. This rather laborious field methodology is essential for a stratigraphic and top view vision of this Mesolithic dump. However, field observations have already provided a partial answer. Among the main species are the mussel Mytilus edulis Linnaeus, 1758, the limpet Patella sp. Linnaeus, 1758, the periwinkle Littorina littorea (Linnaeus, 1758), the cockle Cerastoderma edule (Linnaeus, 1758), the topshell Porcus lineatus (da Costa, 1778), the European clam Ruditapes decussatus (Linnaeus, 1758), the dog whelk Nucella lapillus (Linnaeus, 1758), the

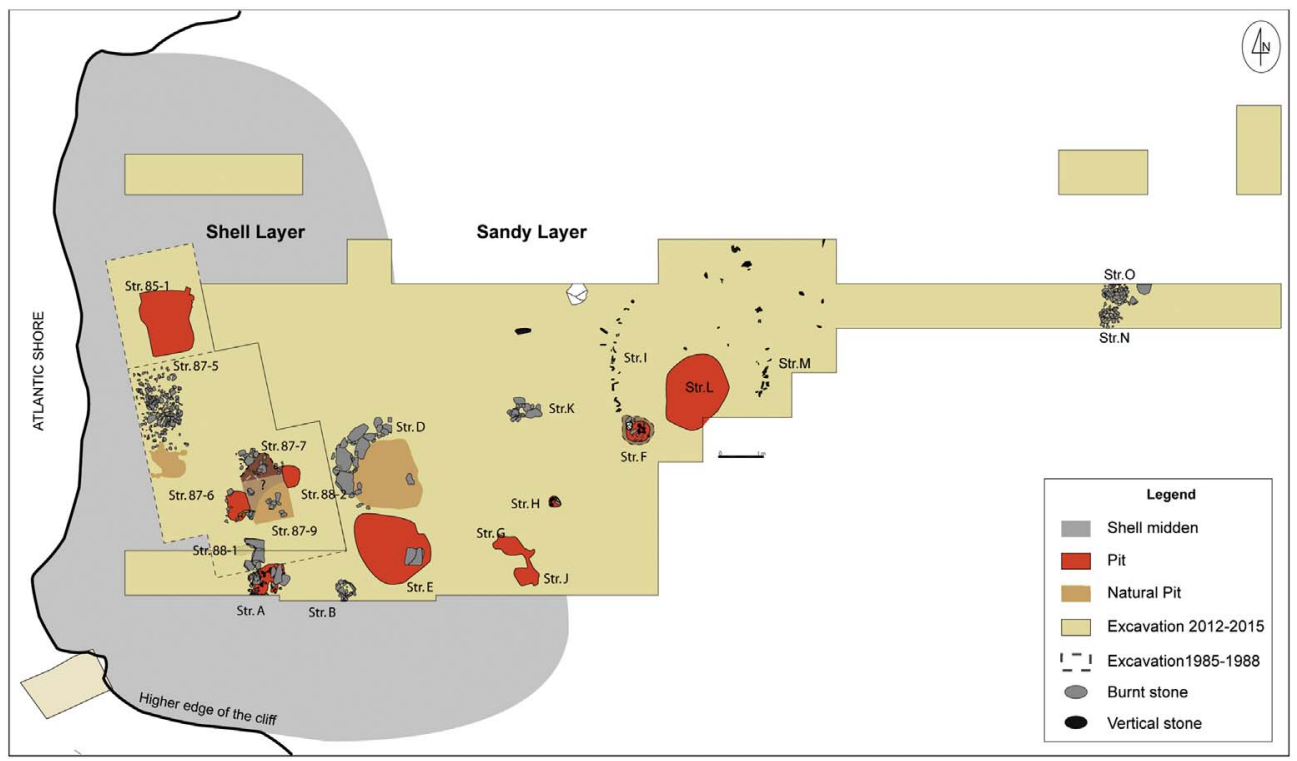

Fig. 3. Map of the site (end of October 2016 campaign) (CAD: G. Marchand and L. Quesnel). 

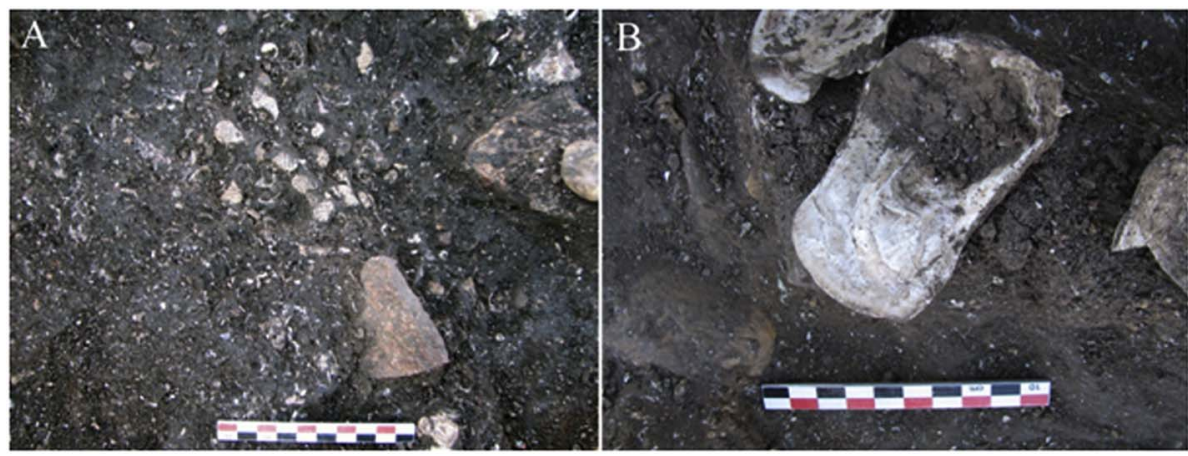

Fig. 4. A - Accumulation of dog whelks trapped in a crevice of the rock, B-Flat oysters associated with burned stones (Picture: C. Dupont).

peppery furrow shell Scobicularia plana (da Costa, 1778) and the flat oyster Ostrea edulis Linnaeus, 1758 (Worms, 2017).

We observe a sequence of accumulations represented by several species only, rather than a homogeneous mass of shells, as if meals targeted one to three species. The latter are visible in pits or natural traps (cracks in the substratum, Fig. 4A). The differential conservation between the shells from the shell midden mass and these trapping structures is interesting. It is perfectly visible by studying the fragmentation of the malacofaunal remains and shows that trampling considerably affected shell fragmentation, in addition to the acidity of the substratum outside the zones where the shells were trapped. The stratigraphy also revealed an accumulation of oysters associated with a level of burnt stones (SU 5.3 and SU 5.4) over the whole surface of the excavated shell level zone (Fig. 4B). This level may be associated with a short duration event but remains enigmatic for now. The dimensions of the oysters imply that they were unquestionably consumed. They were still attached to granite blocks, showing that they were taken from neighbouring foreshore rocks when they were still alive.

Another marked difference is the type of cooking. The oysters display few marks pointing to direct exposure to a source of heat, whereas the present state of knowledge shows that the mussel seems to have been directly exposed to fire. Not one of the thousands of valves observed at Beg-er-Vil is whole. The shell fragments of this species are dark grey, showing that they were exposed to very high temperatures. Once all the specimens have been analysed, we will be able to see if any fire actions are visible in the midden by examining the charring marks observed on these shell remains. The same work could be carried out on all the faunal remains from the site: crustacean (crabs and barnacles), as well as the numerous bird, fish and mammal remains in this anthropic accumulation.

\subsection{And also fine sediments}

Sedimentological analyses were carried out in the heart of the shell midden zone (squares BJ37 and BB31, samples every $2 \mathrm{~cm}$ ). They reveal three main types of facies:

- The samples corresponding to the base of dune, SU 4 and SU 5.1, are equivalent to colluvial coastal sand dunes, infiltrated by silts during these colluvium phases.

- The samples corresponding to SU 5.2, 5.3 and 5.4 are interpreted as phases of more intense remobilization in this reworked coastal dune formation subject to run-off.

- The samples corresponding to SU 5.5, 6 and 7 are characterized by more clayey silts, rich in non-worn quartz grains, interpreted as silty colluviums.

We also note the highest concentration in organic matter and carbonates and/or oxides in SU 6 and 7. Two hypotheses can account for this: the first being migrations of this fine matter in the deepest SU, the second being linked to the development of soils with a high level of human activities in these older humiferous horizons.

\subsection{Trampled shell levels}

The micromorphological analysis of the levels focuses on the three stratigraphic sequences sampled in 2013, in different areas of the zone where the shell level is the thickest (squares: BH32, BH37 and BB32). The identification of features of natural and anthropic origin in the characteristic sedimentary organization enables us to determine the formation processes of the archaeological layers. This is based on established references in pedology and geoarchaeology (Bullock et al., 1985; Wattez, 1992; Gé et al., 1993; Cammas et al., 1996; Wattez et al., 1998; Balbo et al., 2010; Villagran et al., 2011, Villagran 2014).

The layer below the shell layer (SU 7) is formed by a succession of two inputs with a thickness of 2 to $4 \mathrm{~cm}$. They are made up of heterogeneous elements: aggregates of earth mixed with charcoal zones (Fig. 5 a), fragments of fish bones (Fig. 5 b), ash waste (Fig. 5 c and d) and more or less burnt shells resulting from hearth activities. The organization of these elements and the sealing of porosity suggest that these inputs correspond to backfill for spatial organization.

The lower part of the shell level (SU 6, 5.3 and 5.2) results from a deliberate accumulation of occupation waste. These recurrent inputs are 1 to $2 \mathrm{~cm}$ deep and present waste activities linked to combustion: sedimentary zones with abundant charcoal fish bones, bones and more or less burnt shells (some around $700{ }^{\circ} \mathrm{C}$ ) (Fig. 5 e). The upper part of these inputs corresponds to activity surfaces characterized by a subhorizontal reorganization of the coarse components and a sub-horizontal fissure porosity (Fig. $5 \mathrm{f}$ and $\mathrm{g}$ ). The intensity of the mechanical effects of trampling suggested that this waste area beside the activity zones was used frequently.

On the other hand, the formation processes of the upper part of the shell midden change, suggesting a modification in the way the area was used. SU 5.1 is made up of a succession of activity surfaces marked by massive crusts (Fig. $5 \mathrm{~h}$ ). These surfaces are installed on short distance lateral inputs, fine colluviums linked to superficial run-off of limited scope due to the effects of rain (erosion, transfer and deposit over short distances). These activity surfaces develop into exterior zones, as shown by the root and channel porosity which indicates the development of low plant cover. These surfaces are highly structured by the mechanical effects of trampling. This waste area seems to develop into a passage area although we cannot accurately identify the activities that could have been carried out there. These activity surfaces also record alternating dry and wet seasonal conditions.

Lastly, the absence of pedo-sedimentary features marking the resumption of natural processes over anthropic processes underlines a continuous occupation, or at least suggests that the duration of "abandonment" between two occupations is too short to be recorded on a sedimentary scale.

The soil micromorphology analyses call into question the absence of occupation under the shell level and show on the contrary that the currently excavated zone was already on the outskirts of a dwelling 

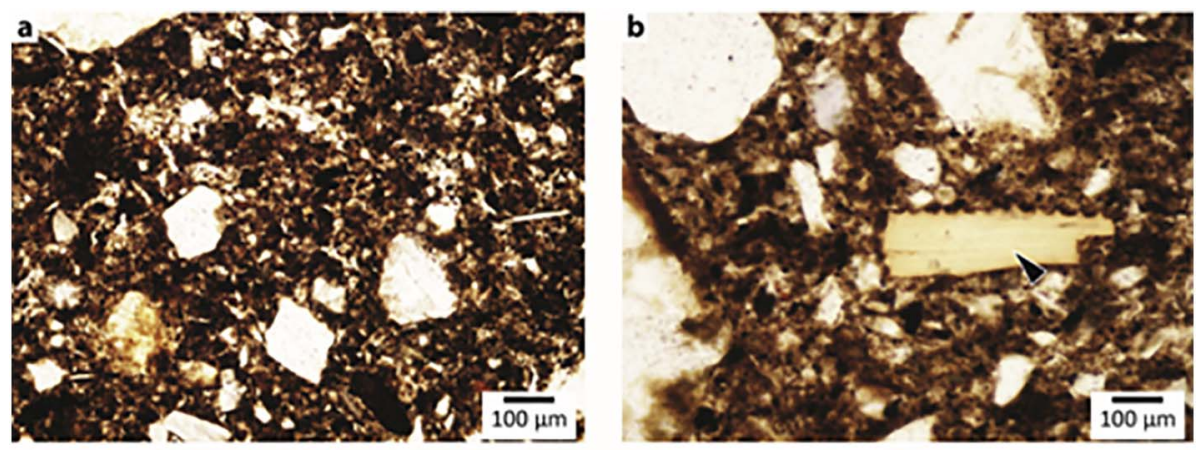

Fig. 5. Micro-photo of thin sections. a: Silty-clay and darkbrown aggregates with high proportion of charcoal microparticles (BH32, LPNA, MPol, $\times 10$ ), b: Fragments of fish bones lightly burned (BB32, LPNA, MPol, $\times 10$ ), c: Clay-carbonated aggregate and wood microcharcoals associated with limited sand: probably ash deposit (BB32, LPNA, $\times 10)$, d: Detail of c (BB32, LPA, $\times 20)$, e: Very fragmented shell burned at very high temperature (BB32, LPNA, $\times 10$ ), f: Activity surface: subhorizontal organization of coarse constituents and fine suhborizontal plate (BH32, LPNA, $\times 4$ ), g: Tooth lying on activity surface marked by horizontal plate (BB32, LPNA, $\times 4$ ), h: Structural massive crust (BH32, LPNA, $\times 4$ ) (Picture: M. Onfray).
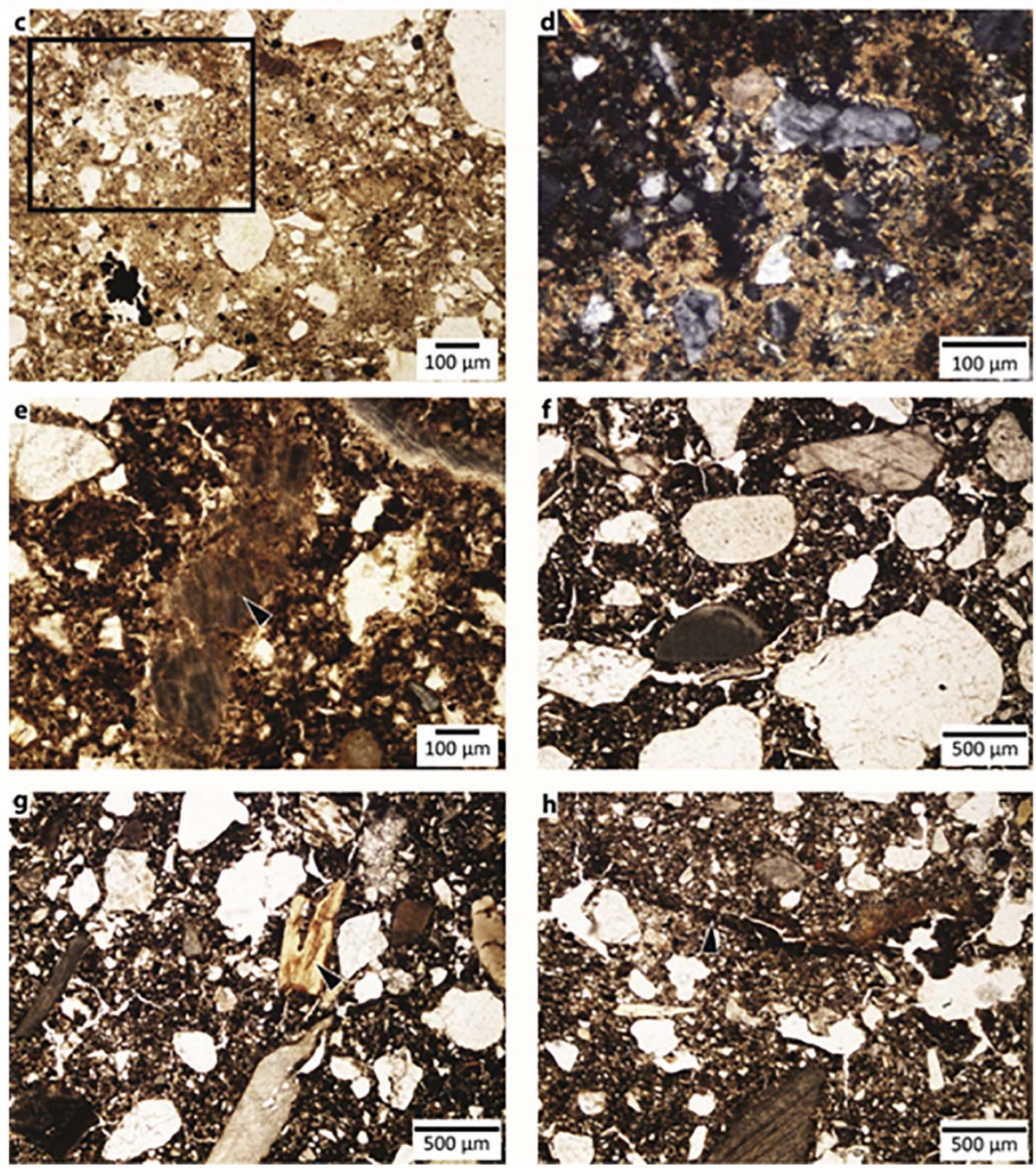

before this area was used.

\section{Internal evolution of the sediments in the shell level}

The conservation of bone remains is closely correlated to the presence of shells, as the dissolution of shells releases carbonates and buffers soil acidity. Systematic sediment samples were taken during the excavations conducted since 2012, per quarter of a square metre and per stratigraphic unit, in order to measure the variation in acidity rates, but also in order to build up a supply for geochemical analyses (Fig. 6). Several types of analyses were conducted: laboratory analysis of the $\mathrm{pH}$ on sediments in and out of the site, in-situ geochemical analyses and laboratory analyses by X-ray fluorescence spectrometry. The aim of these analyses is to bring to light the spatial and chronological organization of Mesolithic settlement at the site with purely chemical parameters, to compare them and relate them (or not) to the different archaeological structures identified, their organization, their evolution. Another methodological aim is linked to the appearance of portable spectrometers, allowing for direct onsite analyses during the excavation. In this way, in situ and laboratory sediment analyses aim to test the validity and interest of in situ geochemical analyses. Lastly, as the site was excavated at two different periods over thirty years apart, we can assess the impact of the excavations on the physico-chemical parameters ensuring the stability of the shell middens over time in terms of taphonomy on the basis of quantitative data.

The $\mathrm{pH}$ measurements were taken following the NF ISO 10390 standard. The soil test sample was taken with a calibrated dosing unit of $2 \mathrm{~cm}^{3}$. The aliquot is suspended by agitation in a decanter of $10 \mathrm{ml}$ of demineralized water with an automatic pipette, with a volumetric soil/ water ratio of $1 / 5$. The conductivity of the water must be inferior to 

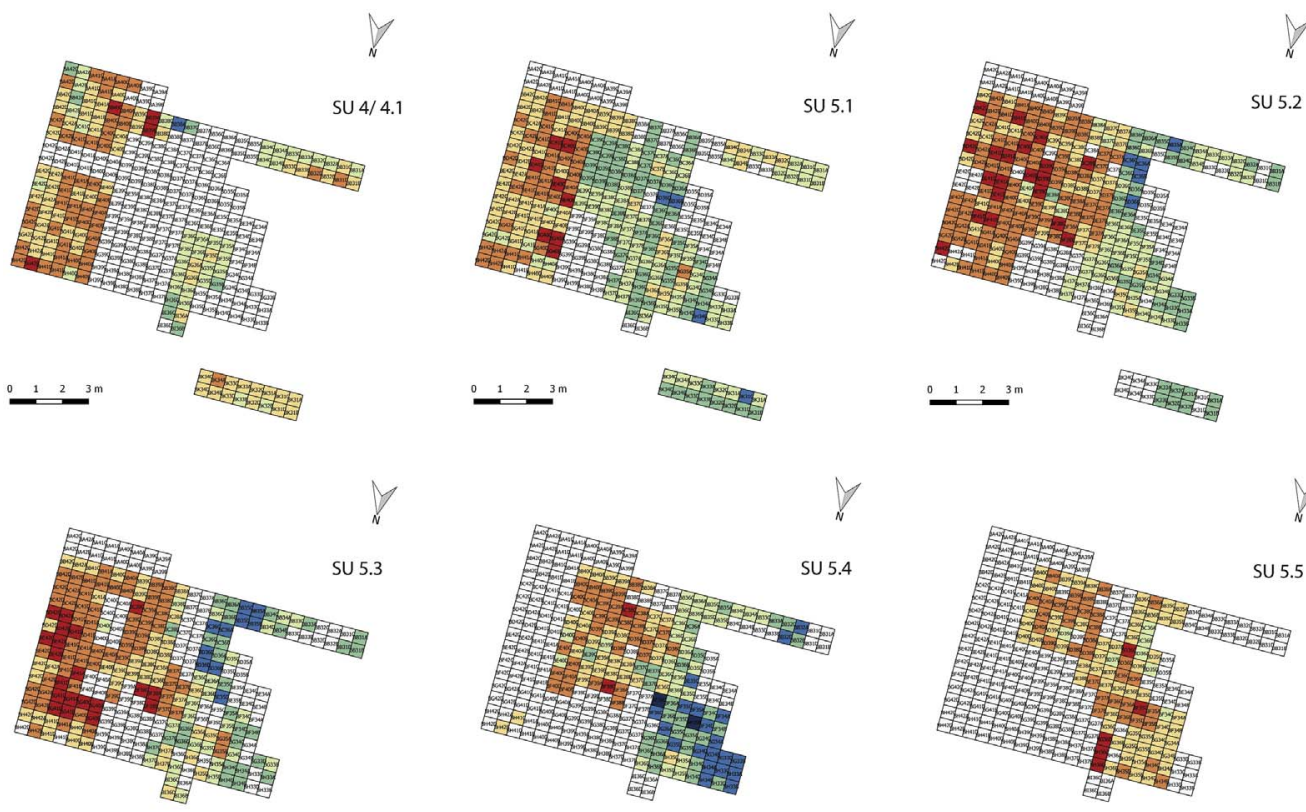

Beg-er-Vil (2012-2015, pH)
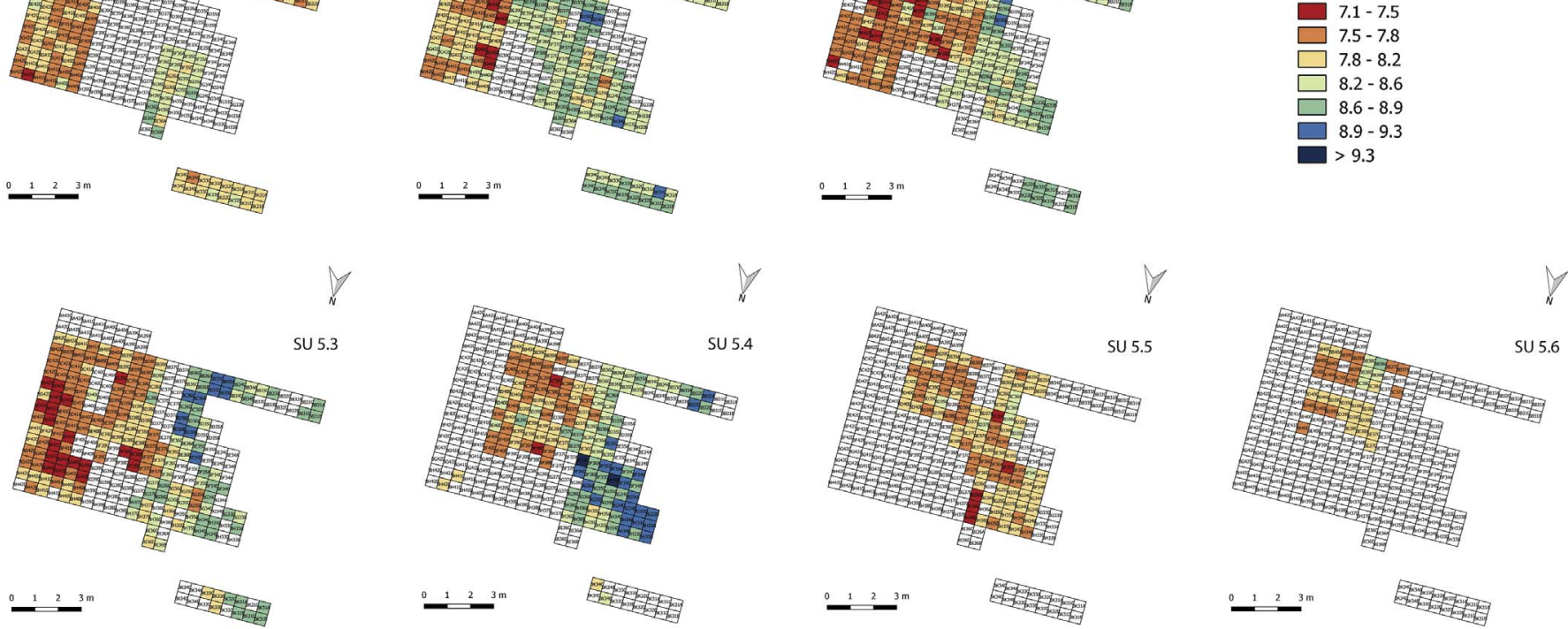

Fig. 6. Measurements of $\mathrm{pH}$ by stratigraphic unit (US 4, 5.1-5.6) and sub square at Beg-er-Vil (excavation 2012-2015) (CAD: D. Nukushina).

$0.1 \mu \mathrm{S} \cdot \mathrm{cm}^{-1}$, in our case $0.054 \mu \mathrm{S} \cdot \mathrm{cm}^{-1}$. In order to reach a state of equilibrium, the $\mathrm{pH}$ measurements are taken from the 1 st to the 24 th hour (measurement accuracy: $0.1 \mathrm{pH}$ unit). This measurement reveals the real acidity or water $\mathrm{pH}$. Nearly a thousand samples were analysed by $\mathrm{pH}$-metry.

Generally, the $\mathrm{pH}$ of archaeological levels varies from 7.7 to 9.0 units, which corresponds to a slightly alkaline to alkaline acid-base status. The homogeneous dune (SU 3) presents a basic $\mathrm{pH}$ (8.2 and 8.4). SU 4, at the interface between the shell level and the dune, shows a unimodal distribution of measurements with an average of $8.3 \mathrm{pH}$ units, a minimum of 7.7, corresponding to a practically neutral sediment and a maximum of 8.7 corresponding to a clearly basic sediment. In the same way, in SU 5.1 (top of the shell level), the average value is $8.5 \mathrm{pH}$ units with the values ranging between 7.8 and $9 \mathrm{pH}$ units, and a unimodal distribution. On the other hand, in SU 5.2, the distribution of the analyses does not follow a normal law; distribution is bimodal with two maxima: one between 8.3 and $8.4 \mathrm{pH}$, the other between 8.6 and $8.7 \mathrm{pH}$. The measurements from layer 5.3 follow a less homogeneous distribution. They do not follow a normal law and their variation curve is at least bimodal if not trimodal. A maximum is situated between 8.2 and 8.4, the second highest between 8.8 and 8.9 and lastly a small peak of the two lowest samples between 7.7 and $7.8 \mathrm{pH}$. This is also the layer for which the variation range is the highest: from 7.7 to $8.9 \mathrm{pH}$.

\section{Organization of the dwelling area}

\subsection{Spatial organization}

The two excavated zones, the shell level and the sandy level, are on different slopes and are linked to different substrata. The shells were spread along a slight slope towards the southwest, which also corresponds to a Pleistocene beach. Further east, the sandy level is almost horizontal and rests directly on the leucogranite base. Both zones also contained different structures.

For now, the eight pits are concentrated in the shell level (Fig. 3). The diameter of the largest pits (85-1, 87-6 and E) measures between 1 and $1.5 \mathrm{~m}$, for a depth of $0.3 \mathrm{~m}$. They are naturally limited by the base rock. Pit 85-1 contained very specific archaeological objects: burnt bone shards, a large schist pebble, backed knives, three armatures, a decorated knife and two fragments of bone tools, a shell (patella, determination C. Dupont) engraved with incisions and three red deer antlers from which the tines had been removed (Poissonnier and Kayser, 1988; Kayser and Bernier, 1988); we can raise questions here as to the intentionality or the votive character of this assemblage. The infill of the other pits is less significant and corresponds to the composition of the shell level. At least for pit E, with a rubified base, we can advance the hypothesis of a pit hearth, subsequently filled in with daily waste.

Combustion activities are also represented by five organized hearths, all of different types: a small pit with a diameter of $30 \mathrm{~cm}$ delimited by rubified slabs standing on their sides (str. B), a natural hollow partially surrounded by large slabs (str. D), a pit with a diameter of $1.50 \mathrm{~m}$ and a depth of $0.50 \mathrm{~cm}$, delimited by intensely rubified slabs leaning at an angle of $45^{\circ}$ (str. L), and two areas of rubified joined stones with a diameter of $0.50 \mathrm{~m}$ (str. $\mathrm{N}$ and $\mathrm{O}$ ). The hearth in pit $\mathrm{L}$, filled with charcoal and burnt bones, is at the centre of a circle of vertically set stones. They delimit a circular area with a diameter of $3.5 \mathrm{~m}$ interpreted as a dwelling. These vertical stones are about $10 \mathrm{~cm}$ long each and were never rubified. They are interpreted as wedges for posts with a diameter of 5 to $8 \mathrm{~cm}$ spaced out by about $20 \mathrm{~cm}$ (Fig. 7).

This spatial division appears to be guided by the topography. The circular dwelling is installed on a level zone (bands 38 to 53), about $4 \mathrm{~m}$ from the shell zone (bands 31 to 37). The latter is used for discarding daily waste, but also for many activities linked to fire. It is important to note the very wide diversity of hearth structures, and the considerable quantities of burnt stones scattered over the whole site, which probably come from repeatedly emptying hearths (flat or pit hearths). Lastly, note that SU 5.3 to 5.5, in the middle of the archaeological shell level, corresponds to a thick layer of blocks altered by the fire, mixed with shells and bone remains. This spread of burnt stones is present over the whole excavated surface, but with a lower density in the sandy zone.

\subsection{Dispersion of the archaeological remains}

In such well-structured areas, how are the archaeological lithic and bone remains spread out? The lithic and bone remains over $20 \mathrm{~mm}$ long were recorded three dimensionally in space using a Total Station, as were the smaller significant objects such as arrow heads or certain 


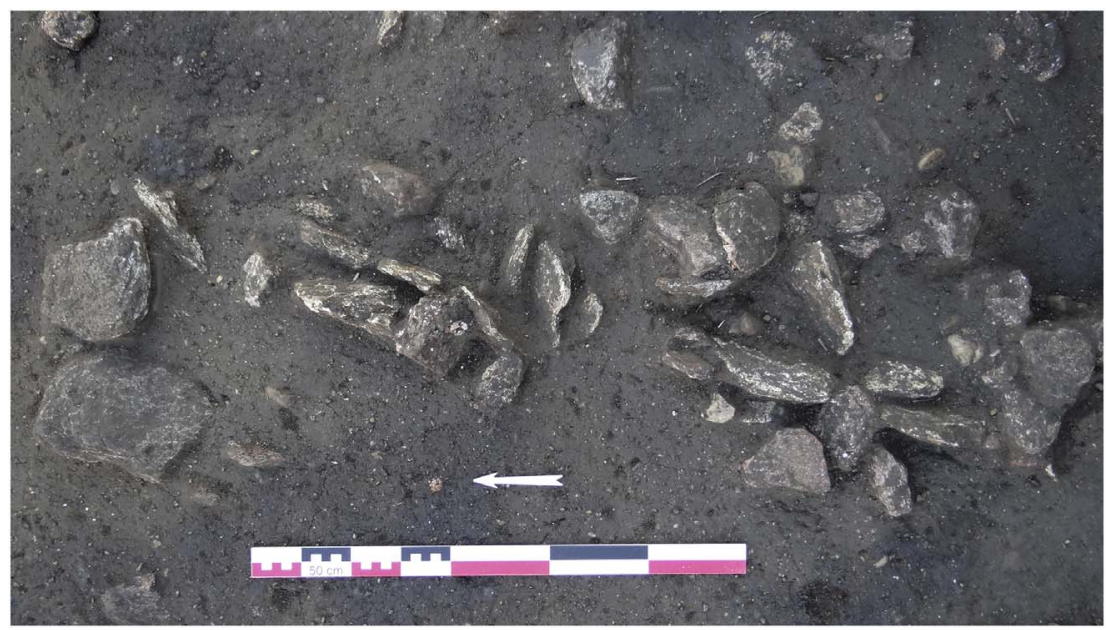

Fig. 7. Standing stones for pickets within the eastern wall of the "hut" (Picture: G. Marchand).

tools. All of the archaeological sediments were wet-sieved with superimposed meshes of $4 \mathrm{~mm}$ and $2 \mathrm{~mm}$, first of all with sea water, then with fresh water. All the sieve remains were fully sorted in the laboratory for the $4 \mathrm{~mm}$ mesh. They were observed, then only partially sorted for the $2 \mathrm{~mm}$ mesh.

For the moment, spatial analysis by GIS only concerns the shell zone and only the 7420 objects recorded between 2012 and 2015 (Fig. 8). The vast majority of these objects $(89.9 \%)$ are lithics, for which technological and typological analyses were carried out. The data obtained were cross-examined with the spatial information. Complementary data concerning lithics or shells were obtained from the sieve residue. This reintegration of sieved objects does not drastically change the overall perspective, except for armatures, as on average, $84.1 \%$ of them were collected from sieves.

The lithic objects are clearly more abundant in the shell levels (81.0\% in total in SU 5.1 to 5.5), particularly in SU $5.3(23.1 \%)$ and SU $5.2(21.5 \%)$. The structure infills present high quantitative variations, with a lot of objects in some of them, such as structure $\mathrm{D},(0.9 \%$ of the total of recorded lithic objects), but no concentration of tools or specific waste was identified.

The spatial distribution of the recorded objects (lithics, bones, shells) thus shows a high concentration to the west of the excavated zone, in the shell level. The lithic objects and the bones in particular are concentrated in the northwest part, which coincides with the highest thickness of shells and the lowest acidity. In fact, the structures do not correspond to the highest concentrations of objects, apart from structure D (hearth) and structure I (alignment of post holes). Also, overall, the mapping of the different categories of lithic objects (raw materials, types of objects or dimensions) does not suggest distinct distributions. Only the hammer stones seem to be particularly concentrated in the northwest zone, although there is no accumulation of flint debitage or bone breakage area in this zone.

In so far as the shell zone is on a slight slope towards the southwest (tilt of approximately $50 \mathrm{~cm}$ over $10 \mathrm{~m}$ along an E-W axis, perceptible in the altimetric layout of the analysed lithics) and in a rather loose silty sandy context, the concentration of objects from the northwest zone may partially result from erosive processes and more exactly from reorganization subsequent to the sedimentary deposits. Considering the altimetry of the recorded objects in the main sedimentary units, this question of post-depositional reorganization of the remains deserves to be discussed in the future. However, gravity does not seem to be responsible for the homogeneous character of the dispersion of archaeological remains: it is rather the result of circulation and the use of a central zone in the dwelling.

\section{Chronology of the occupations}

The very homogeneous stylistic characters of the lithic industry and the almost total domination of symmetric trapezes (used as cutting arrows) among the armatures indicates a rather short occupation period, as we know that these types of tools vary a lot during the Mesolithic. The first two radiocarbon dates obtained at Beg-er-Vil were distorted, the first by a sampling problem and the second by the oceanic reservoir effect (Marchand et al., 2016). Additional dating on shortlived samples (a roe deer bone, twigs and burnt fruit) were conducted on samples from the 1980s excavations (Table 1). Generally, samples of marine origin are no longer used for dating (Marchand et al., 2009). The new dating are between 6250 and 6000 BCE. They were confirmed by three new measurements obtained on samples from the 2014 excavation. The aim was to have a dating of the structure $\mathrm{E}$ (a pit) and structure D (the large hearth), but also the level of burnt stones (SU 5.3). The first two are totally coherent with the date of pit 87-6 discovered by O. Kayser. On the other hand, the dating from SU 5.3 $(7320 \pm 30 \mathrm{BP})$ is a little older than predicted, if we compare it to the dating obtained from the Kayser excavation below this stone (spits 3 and 9 from level 3B, which is the equivalent of SU 5.5 and 8). The gap is not enormous and may be due to an old wood effect as it is one of the rare samples that is not short-lived.

All these dates are within the same 7300/7200 BP interval, which unfortunately corresponds to a plateau that affects the calibration curve around 7300 BP (non-calibrated), which somewhat spreads out the oldest dates. On the other hand, the calibration of the dates around $7200 \mathrm{BP}$ is excellent and remarkably secures the upper part of the shell level. This improved chronological position not only means that Beg-erVil is the oldest known shell midden in Brittany, but also places it entirely in a major climatic deterioration of the Holocene, the "Finse Event", with a diversely appreciated chronological position, but always within the last two centuries of the millennium (Thomas et al., 2007; Kobashi et al., 2007; Matero et al., 2017). The effects of this cooling on the captured fauna and the vegetation are currently being evaluated.

\section{Erosive dynamics of marine origin}

The stratigraphic, sedimentological, micromorphological and archaeological analysis deal with the dynamics of site formation. Now these should be linked to other erosive dynamics that have masked or altered the archaeological signals.

To the right of the Beg-er-Vil site, the foreshore is a vast hollowed zone dotted with major rocky massifs forming 3 to $4 \mathrm{~m}$ high reefs, which protect the shoreline from wave erosion in places. These reliefs are delimited by a network of parallel or perpendicular joints, where the main ones are oriented WSW-ENE and follow the foreshore, and 


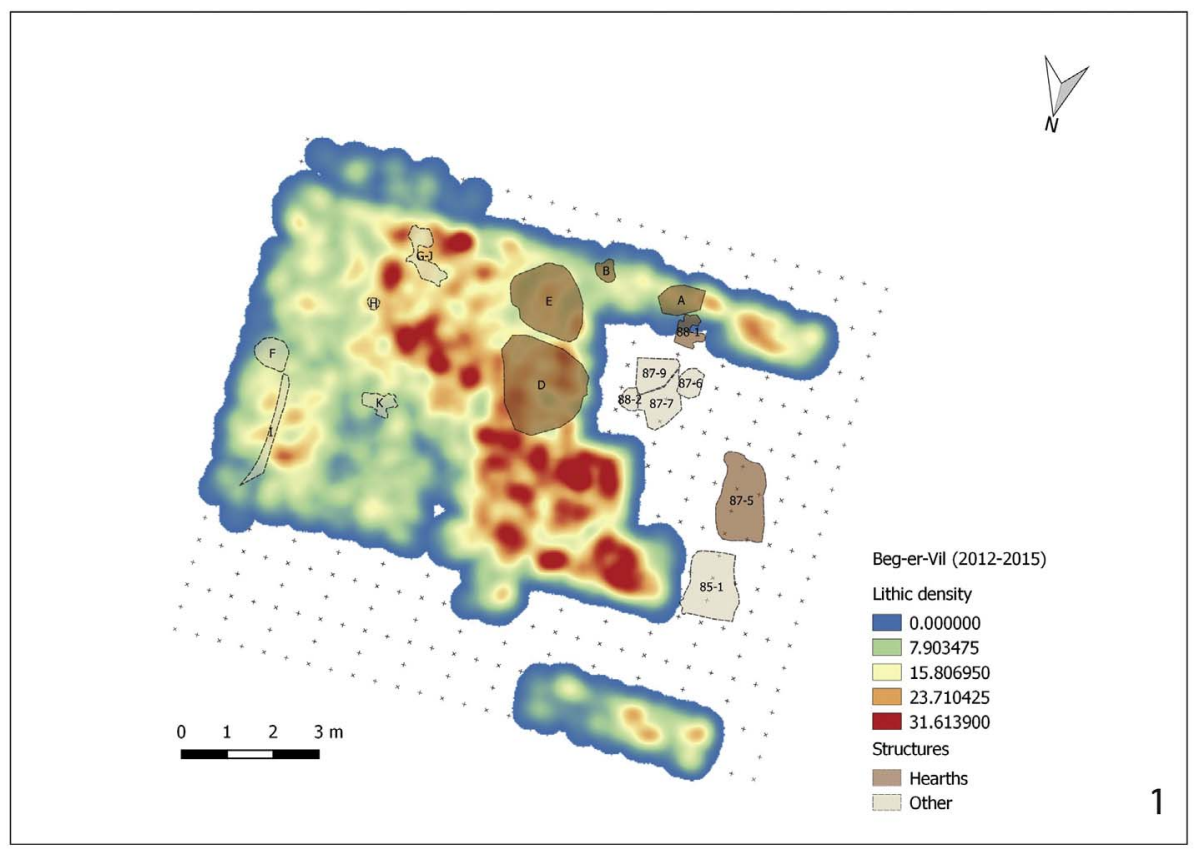

Fig. 8. Beg-er-Vil (2012-2015 excavations). 1: Kernel density map based on the piece-plotted lithics from the excavated area of Beg-er-Vil and structures; 2: Kernel density map based on the piece-plotted bone remains (left) and shells (right); 3: Distribution of armatures by square (pieceplotted pieces and those recovered from sieving) and some examples from 2015s campaign (original photos: François Eluard; CAD: D. Nukushina).
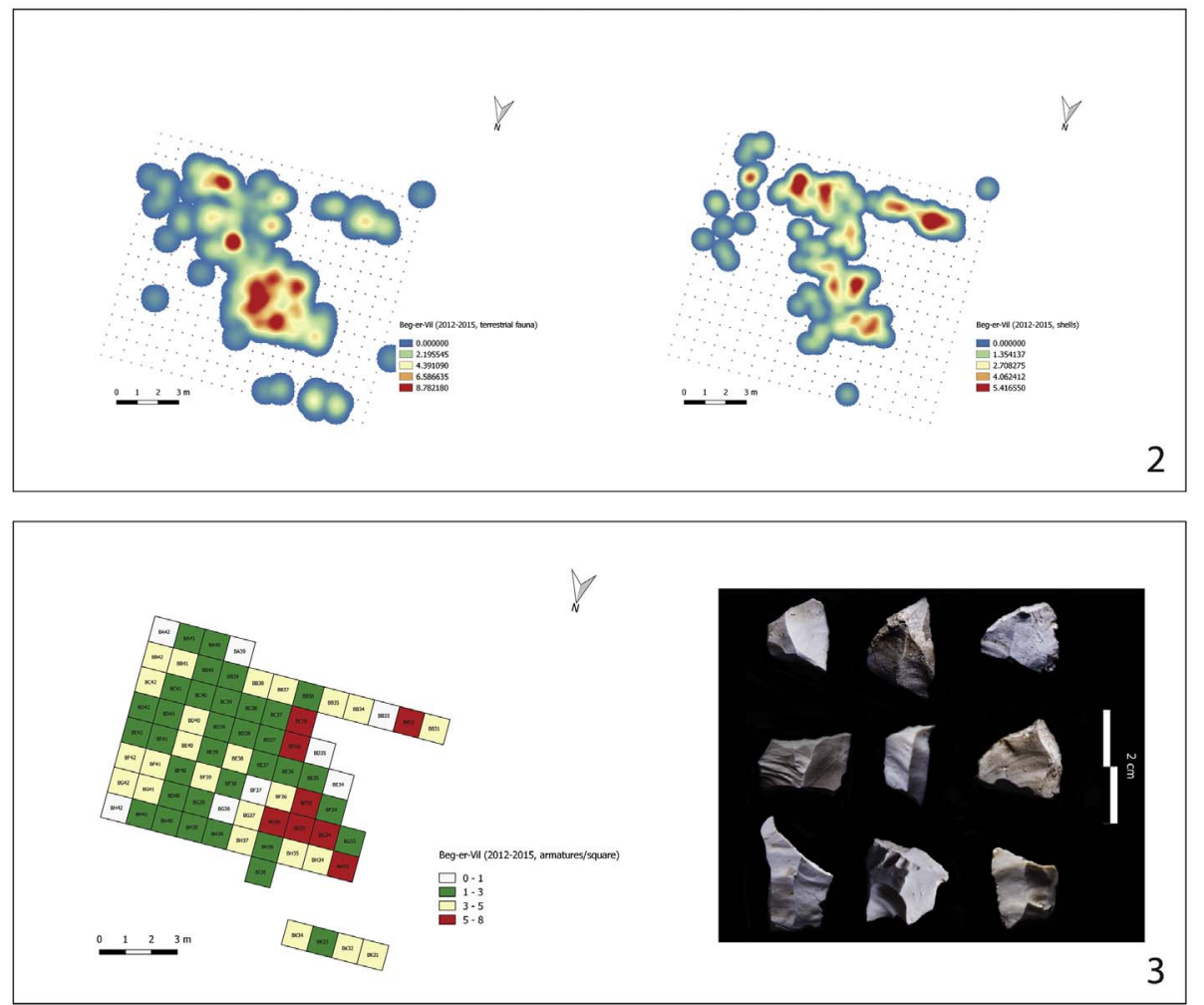

probably extend under the loose Pleistocene and Holocene cover. In the zones where the joints are the most marked and where there are no reefs, the coastline is sculpted into 4 to $5 \mathrm{~m}$ high cliffs in loose materials (former beach and Holocene dune). The aerial photographs of Beg-erVil head taken during the past eight decades were analysed (national Photo library, BD ORTHO of the IGN, Geolittoral of the Ministry of Ecology, Sustainable Development and Energy). The aerial images taken in 1932, 1947, 1964, 2008 and 2011, with higher spatial and spectral resolution than the others, show that the Beg-er-Vil site shows slight modifications, apart from in several restricted sectors. The highest retreat rates are observed to the right of the former hollows of the rocky outcrop, sealed by marine sediments of Pleistocene age and now shaped by the sea into cliffs made up of loose materials. Thus, at the back of the bay, the recession of the coast line since 1932 reaches $6.4 \pm 0.86 \mathrm{~m}$ in places. The southern side of the archaeological site of Beg-er-Vil was thus relatively protected from marine erosion during the past eight decades, in comparison to the northern side.

The shoreline position during the Beg-er-Vil settlement was estimated in time and space by simulating the post-glacial relative sea-level rise on a pre-transgressive relief using several sets of local data (Fig. 9). A map of the past foreshore areas is proposed according to: (i) the accuracy of the bathymetric data used; (ii) the presence/absence of a marine Holocene sediment cover overlying the Pleistocene substratum in places, (iii) the age and thickness of the sediment covering; (iv) the 
Table 1

Radiocarbon dating of the Beg-er-Vil shell midden on materials gathered during all the excavations. The dating were calibrated with the Oxcal 4.2 program, with the INTCAL 13 curve (Reimer et al., 2013). It is given here with two sigma, or 95.4\% probability. The interval of the dates in brackets corresponds to maximum probabilities. The first dating obtained (in grey in the table) is not calibrated again. The measure of the radiocarbon of the wild boar bone appears to older because of marine reservoir effect.

\begin{tabular}{|c|c|c|c|c|c|}
\hline Stratigraphic origin & Lab code & $\begin{array}{l}\text { Conventional date } \\
\text { (BP) }\end{array}$ & $\begin{array}{l}\mathrm{C} 13 / \mathrm{C} 12 \\
(0 / 00)\end{array}$ & Materials & Calibration 2 sigma \\
\hline Shell midden & Gif-7180 & $6020 \pm 80$ & Unknown & Shell & - \\
\hline $\begin{array}{l}\text { Layer 3B - Spit6 - AG } \\
23-164\end{array}$ & OxA-25916 & $7193 \pm 36$ & -21.61 & $\begin{array}{l}\text { Bone - } \\
\text { Capreolus } \\
\text { capreolus }\end{array}$ & $\begin{array}{l}6204-5992 \\
(6110-5992)\end{array}$ \\
\hline $\begin{array}{l}\text { Layer 3B - Spit6 - } \\
\text { Square AH21 }\end{array}$ & Beta-253153 & $7210 \pm 50$ & -27.2 & Fruit & $6211-6004$ \\
\hline $\begin{array}{l}\text { Layer 3A - Spit2 - } \\
\text { AH20 }\end{array}$ & Beta-274301 & $7220 \pm 50$ & -27.1 & Fruit & $6212-6010$ \\
\hline $\begin{array}{l}\text { SU } 42 \text { - SquareBC37 } \\
\text { (Pit E) }\end{array}$ & Beta-421804 & $7280 \pm 30$ & -26.0 & Fruit tree twig & $6225-6065$ \\
\hline SU 5.3 - Square BG36 & Beta-421805 & $7320 \pm 30$ & -23.8 & Oak & $6235-6085$ \\
\hline $\begin{array}{l}\text { Layer 3B - Spit } 6 \text { - } \\
\text { Square AH21 }\end{array}$ & Beta-253154 & $7300 \pm 50$ & -24.9 & Fruit tree twig & $6250-6050$ \\
\hline $\begin{array}{l}\text { Layer 3B - Spit } 9 \text { - } \\
\text { Square AG } 20\end{array}$ & OxA-25915 & $7332 \pm 35$ & -22.08 & $\begin{array}{l}\text { Bone - } \\
\text { Capreolus } \\
\text { capreolus }\end{array}$ & $\begin{array}{l}6326-6076 \\
(6252-6076)\end{array}$ \\
\hline $\begin{array}{l}\text { Layer 3B - Spits 8-9 - } \\
\text { Square AF20 (Pit 1) }\end{array}$ & Beta-259108 & $7340 \pm 40$ & -25.1 & Fruit tree twig & $\begin{array}{l}6350-6074 \\
(6264-6074)\end{array}$ \\
\hline $\begin{array}{l}\text { SU } 32 \text { - Square BD36 C } \\
\text { (Pit D) }\end{array}$ & Beta-421803 & $7350 \pm 30$ & -25.0 & Fruit tree twig & $6250-6105$ \\
\hline $\begin{array}{l}\text { Layer 3B - Spit } 6 \text { ou } 7 \text { - } \\
\text { Square AG } 20\end{array}$ & OxA-16563 & $7568 \pm 41$ & -16.5 & $\begin{array}{l}\text { Bone - Sus } \\
\text { scrofa }\end{array}$ & $6490-6372$ \\
\hline
\end{tabular}

uncertainties of the relative sea-level reconstructions, (v) the tidal range variations. The coastal topo-bathymetric DEM carried out as part of the TANDEM project by the French Hydrographic Office was used for the studied area. This DEM was originally developed to be implemented in the hydrodynamic models. It covers a large part of southern Brittany. The spatial resolution of the data is $0.0002^{\circ}(\sim 20 \mathrm{~m})$, with a vertical accuracy of less than $0.5 \mathrm{~m}$. The vertical datum corresponds to the Lowest Astronomical Tide (LAT). Several sources of bathymetric data were used to produce this DEM: historic lead line soundings, single and multibeam surveys, echo-soundings, topographic and bathymetric Lidar surveys. Due to the possible presence of marine Holocene sediment cover, the DEMs used sometimes give an erroneous picture of pretransgressive relief. In this case, the sediment thickness over the Pleistocene substratum needs to be subtracted from the DEMs before simulating the post-glacial relative sea-level rise on reconstructed bathymetry. A review of the marine sedimentology studies carried out close to the studied areas was undertaken to estimate the sediment cover in terms of geometry, age and thickness. The review of the literature indicates that the eastern part of Quiberon peninsula shows a complex thick sediment cover and the presence of a pre-transgressive paleo-fluvial channel network (submerged valley of the Vilaine River) filled with Holocene marine sediment (Menier, 2003; Proust et al., 2001). However, the studies carried out in the vicinity of the archaeological site of Beg-er-Vil from seismic data indicate that Holocene sediment cover never exceeded a depth of $1 \mathrm{~m}$. Some studies have highlighted significant changes in tidal range along the European coasts during the Holocene (Uehara et al., 2006; Neill et al., 2010) with possible effects on the extension of foreshore areas. For this reason, the paleotide modellings developed along the Atlantic and English Channel coasts (Neill et al., 2010) were used to correct the effects of tidal range variations. The past mean spring tide range modelled was compared to the present-day value calculated from tide gauges (SHOM, 2013). Finally, the difference between past and present values was added to the minimal and maximal values of tide levels. The relative sea-level records available in Brittany for the period 6200-6100 BCE were collected from the sea-level database produced by Stéphan and Goslin 


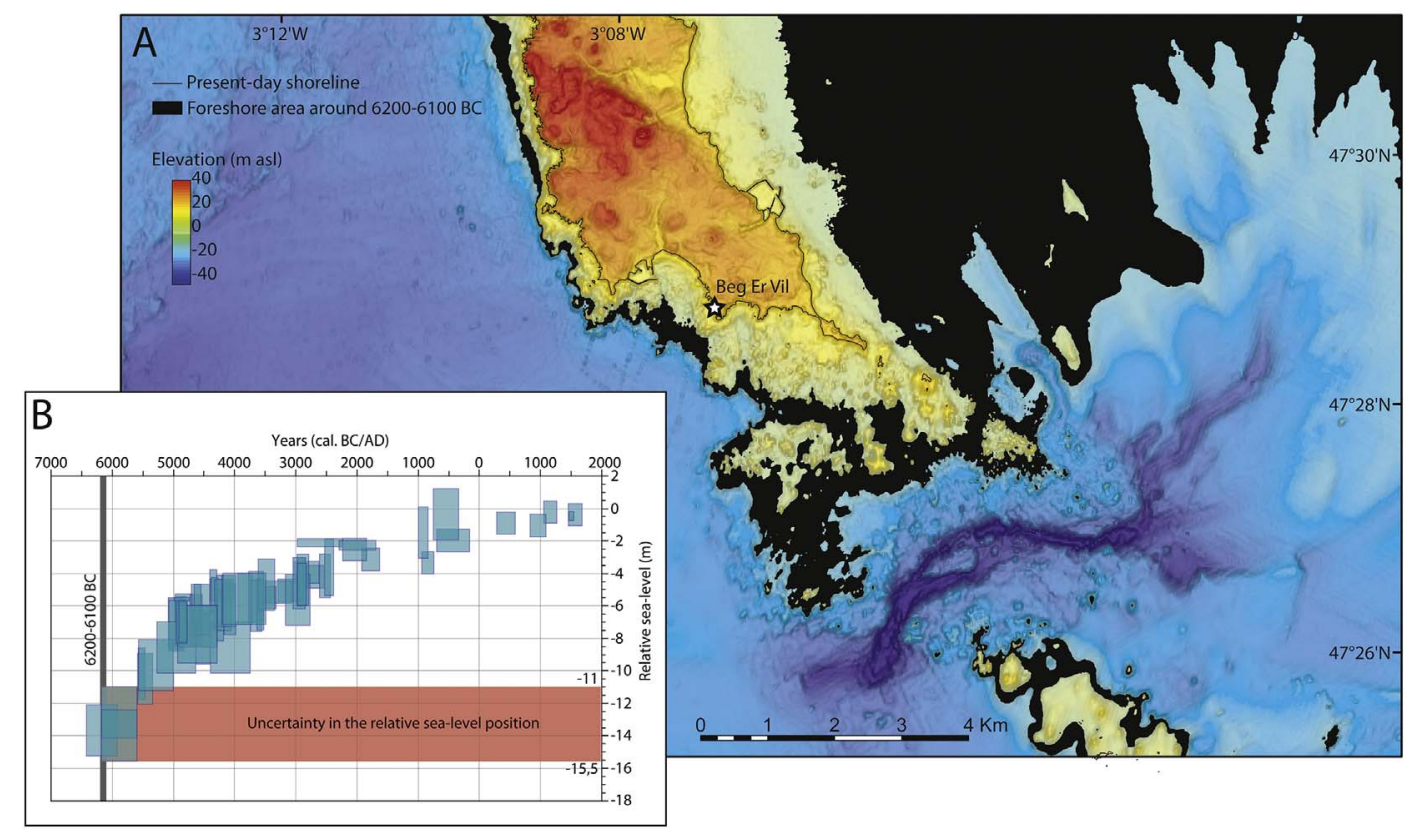

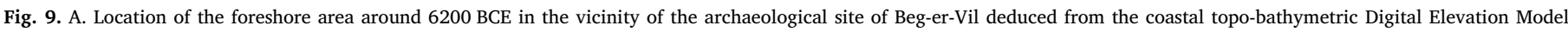

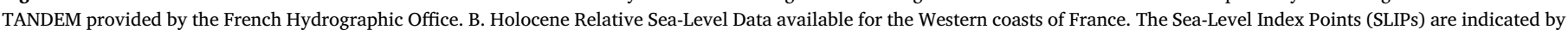

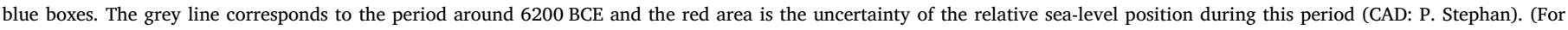
interpretation of the references to color in this figure legend, the reader is referred to the web version of this article.)

(2014). Data collected from 54 research papers were reassessed using the "Sea-Level Index Points" (SLIPs) methodology (Hijma et al., 2015) in order to propose a reliable reconstruction of Holocene relative sealevel rise along the whole French Atlantic and English Channel coasts of France. Three SLIPs indicate a relative sea-level position between $-15.5 \mathrm{~m}$ and $-11 \mathrm{~m}$ and a foreshore area at a depth between -7.15 and $-14.02 \mathrm{~m}$ around $6200 \mathrm{BCE}$. This approach to paleogeographic reconstruction indicates that the site of Beg-er-Vil was located a few hundred meters to a few kilometres from the coastline.

\section{Conclusion}

During the past five years, sieving and dry sorting protocol has been implemented. Considered individually, none of the parameters examined during this operation was sufficient for reconstructing spatial organization, which is impossible to assess using a direct visual approach. We paid particular attention to taphonomic conditions, which clearly influence subsequent paleoethnographic interpretations, but also dietary reconstructions by taking into account all the types of animal and plant food. In spite of tests, it was not possible to retrieve pollen grains, phytoliths or paleoparasites due to the sandy nature of the sediments. Lastly, the effects of marine erosion can only be evaluated for the past 80 years on the basis of aerial photographs, and this is a very restrictive factor as we cannot estimate the quantity of sediments carried away by the waves.

By taking these limits into account, the first results obtained by our team enable us to describe a Mesolithic dwelling with very varied domestic functions, with daily waste abandoned to the west of the site over a slight slope towards the ocean and a flatter zone to the east, where at least one circular hut was erected. The micromorphological study implies that there was no prolonged phase of abandonment over the two centuries of occupation. This interval is "short" in comparison to most Atlantic Mesolithic sites, but not sufficient for dealing with the challenges here. We have planned to refine the chronological results using a Bayesian age model, but only when new radiocarbon dates have been obtained for each structure. The functional or paleothnographic analysis mentioned in the introduction of this article are now essential in order to enhance our understanding of the sequence of activities carried out at this site during the course of the seasons. This is a crucial condition for defining the status of this dwelling within a broader economic network, or rather the statuses, as the stratigraphy shows several transformations over the course of time.

\section{References}

Balbo, A.L., Madella, M., Vila, A., Estévez, J., 2010. Micromorphological perspectives on the stratigraphical excavation of shell middens: a first approximation from the ethnohistorical site Tunel VII, Tierra del Fuego (Argentina). J. Archaeol. Sci. 37, 1252-1259. http://dx.doi.org/10.1016/j.jas.2009.12.026.

Bullock, P., Fedoroff, N., Jonguerius, A., Stoops, G., Tursina, T., Babel, U., 1985. Handbook for Soil Thin Section Description. Waine Research, Albrighton.

Cammas, C., Wattez, J., Courty, M.-A., 1996. In: Castelleti, L., Cremaschi, M. (Eds.), L'enregistrement sédimentaire des modes d'occupation de l'espace. Paleoecology, XIII International Congress of Prehistoric and Proto-historic Sciences. 3 A.B.A.C.O., Forli.

Dupont, C., Tresset, A., Desse-Berset, N., Gruet, Y., Marchand, G., Schulting, R., 2009. Harvesting the seashores in the Late Mesolithic of north-western Europe. A view from Brittany? J. World Prehist. 22 (2), 93-111.

Gé, T., Courty, M.-A., Matthews, W., Wattez, J., 1993. Sedimentary formation processes of occupation surfaces. In: Goldberg, P., Nash, Pétraglia, M.D. (Eds.), Formation Processes in Archaeological Context, Monographs in World Archaeology. Prehistory press, Madison, pp. 149-163.

Hijma, M.P., Engelhart, S.E., Törnqvist, T.E., Horton, B.P., Hu, P., Hill, D.F., 2015. A protocol for a geological sea-level database. In: Shennan, I., Long, A.J., Horton, B.P. (Eds.), Handbook of Sea-level Research. Wiley \& Sons, Oxford, pp. 470-499.

Kayser, O., Bernier, G., 1988. Nouveaux objets décorés du Mésolithique armoricain. Bulletin de la Société Préhistorique Française 85 (2), 45-47.

Kelly, R., 2007. The Foraging Spectrum. Diversity in Hunter-Gatherer Lifeways. Percheron Press, New York, pp. 446.

Kobashi, T., Severinghaus, J.P., Brook, E.J., Barnol, A.J.-M., Grachev, A.M., 2007. Precise timing and characterization of abrupt climate change 8200 years ago from air trapped in polar ice. Quat. Sci. Rev. 26, 1212-1222.

Marchand, G., 2013. Le Mésolithique insulaire atlantique: systèmes techniques et mobilité humaine à l'épreuve des bras de mer. In: Daire, M.-Y., Dupont, C., Baudry, A., Billard, C., Large, J.-M., Lespez, L., Normand, E., Scarre, C. (Eds.), Ancient Maritime Communities and the Relationship Between People and Environment Along the European Atlantic Coasts/Anciens Peuplements Littoraux et Relations Home/Milieu Sur Les côtes de l'Europe Atlantique. Proceedings of the HOMER 2011 Conference, British Archaeological Reports (B.A.R.). pp. 359-369 International Series.

Marchand, G., 2014. Préhistoire atlantique. Fonctionnement et évolution des sociétés du Paléolithique au Néolithique. Éditions Errance, Arles.

Marchand, G., Dupont, C., Oberlin, C., Delque-Kolic, E., 2009. Entre "effet réservoir" et "effet de plateau" : la difficile datation du Mésolithique de Bretagne. In: Crombé, Ph., Van Strydonck, M., Sergant, J., Bats, M., Boudin, M. (Eds.), Chronology and Evolution in the Mesolithic of NW Europe. Proceedings of the international congress, Brussels, May 30 - June 1 2007. Cambridge Scholar Publishing, pp. 297-324. 
Marchand, G., Dupont, C., Delhon, C., Desse-Berset, N., Gruet, Y., Laforge, M., Le Bannier, J.-C., Netter, C., Nukushina, D., Onfray, M., Querré, G., Quesnel, L., Stéphan, P., Tresset, A., 2016. Retour à Beg-er-Vil. Nouvelles approches des chasseurs-cueilleurs maritimes de France Atlantique. In: Dupont, C., Marchand, G. (Eds.), Archéologie des chasseurs-cueilleurs maritimes. De la fonction des habitats à l'organisation de l'espace littoral, Actes de la séance de la Société préhistorique française de Rennes, 10-11 avril 2014, Paris, Société préhistorique française, 2016, pp. 283-319(Séances de la Société préhistorique française, 6), http://www.prehistoire.org/offres/file_inline_src/ 515/515_P_41148_58512e3e298f5_14.pdf.

Marchand, G., Dupont, C., 2017. Beg-er-Vil ou la transformation d'un amas coquillier en habitat littoral, Bulletin de la Société Préhistorique Française. Actualités scientifiques 114 (2), 373-375.

Matero, I.S.O., Gregoire, L.J., Ivanovic, R.F., Tindall, J.C., Haywood, A.M., 2017. The 8.2 ka cooling event caused by Laurentide ice saddle collapse. Earth Planet. Sci. Lett. 473, 205-214. http://dx.doi.org/10.1016/j.epsl.2017.06.011.

Menier, D., 2003. Morphologie et remplissage des vallées fossiles sud-armoricaines: apports de la stratigraphie sismique. PhD Thesis University of Southern Brittany.

Neill, S.P., Scourse, J.D., Uehara, K., 2010. Evolution of bed shear stress distribution over the northwest European shelf seas during the last 12,000 years. Ocean Dyn. 60, 1139-1156. http://dx.doi.org/10.1007/s10236-010-0313-3.

Poissonnier, B., Kayser, O., 1988. Les bois de cerfs mésolithiques de Beg-er-Vil à Quiberon (Morbihan), Revue Archéologique de l'Ouest. 5. pp. 35-43.

Proust, J.-N., Menier, D., Guillocheau, F., Guennoc, P., Bonnet, S., Rouby, D., Le Corre, C., 2001. Les vallées fossiles de la baie de la Vilaine: nature et évolution du prisme sédimentaire côtier du Pléistocène armoricain. Bull. Soc. Geol. Fr. 172, 737-749.

Reimer, P.J., Bard, E., Bayliss, A., Beck, J.W., Blackwell, P.G., Bronk Ramsey, C., Buck, C.E., Cheng, H., Edwards, R.L., Friedrich, M., Grootes, P.M., Guilderson, T.P., Haflidason, H., Hajdas, I., Hatté, C., Heaton, T.J., Hoffmann, D.L., Hogg, A.G., Hughen, K.A., Kaise, R.K.F., Kromer, B., Manning, S.W., Niu, M., Reimer, R.W., Richards, D.A., Scott, E.M., Southon, J.R., Staff, R.A., Turney, C.S.M., van der Plicht, J., 2013. IntCal13 and Marine13 radiocarbon age calibration curves 0-50,000 years cal BP. Radiocarbon 55 (4), 1869-1887.
Sassaman, K.E., 2004. Complex hunter-gatherers in evolution and history: a northamerican perspective. J. Archaeol. Res. 12 (3), 227-280.

Uehara, K., Scourse, J.D., Horsburgh, K.J., Lambeck, K., Purcell, A.P., 2006. Tidal evolution of the northwest European shelf seas from the last glacial maximum to the present. J. Geophys. Res. 111, 025, C09.

Stéphan, P., Goslin, J., 2014. Holocene relative sea-level rise along the Atlantic and English channel coasts of France: reassessment of existing data using "Sea-level index points" method. Quaternaire 25 (4), 295-312.

SHOM, 2013. Références Altimétriques Maritimes. http://data.shom.fr.

Testart, A., 1982. Les chasseurs-cueilleurs ou l'origine des inégalités, Paris, Société d'Ethnographie.

Thomas, E.R., Wolff, E.W., Mulvaney, R., Steffensen, J.P., Johnsen, S.J., Arrowsmith, C., White, J.W.C., Vaughn, B., Popp, T., 2007. The 8.2 ka event from Greenland ice cores. Quat. Sci. Rev. 26 (1-2), 70-81 (January 2007).

Villagran, X.S., 2014. A redefinition of waste: deconstructing shell and fish mound formation among coastal groups of southern Brazil. J. Anthropol. Archaeol. 36, 211-227. http://dx.doi.org/10.1016/j.jaa.2014.10.002.

Villagran, X.S., Balbo, A.L., Madella, M., Vila, A., Estevez, J., 2011. Stratigraphic and spatial variability in shell middens: microfacies identification at the ethnohistoric site Tunel VII (Tierra del Fuego, Argentina). Archaeol. Anthropol. Sci. 3, 357-378. http:// dx.doi.org/10.1007/s12520-011-0074-z.

Wattez, J., 1992. Dynamique de formation des structures de combustion de la fin du Paléolithique au Néolithique moyen: approche méthodologique et implications culturelles. Paris 1 Panthéon Sorbonne, Paris.

Wattez, J., Cammas, C., Courty, M.-A., 1998. Marqueurs spatio-temporels des ambiances pédo-climatiques dans les sols archéologiques. Spatio-temporal indicators of environmental settings in archaeological soils. In: Congrès Mondial de Science Du Sol, Montpellier, France, Août 1998.

Worms, 2017. World Register of Marine Species. http://www.marinespecies.org.

Yesner, D., 1980. Maritime Hunter-Gatherers: ecology and prehistory. Curr. Anthropol. 21, 727-750 (6. Dec., 1980). 